\title{
PERILAKU INVESTASI ANAK PADA KELUARGA MISKIN DAN TIDAK MISKIN
}

\author{
Nofia Mutiara Bahri $\left.{ }^{*}\right)$, Hartoyo ${ }^{1}$ \\ ${ }^{1}$ Departemen IImu Keluarga dan Konsumen, Fakultas Ekologi Manusia, Institut Pertanian Bogor, \\ Bogor 16680, Indonesia \\ ${ }^{*}$ Email:nofiamutiara@gmail.com
}

\begin{abstract}
Abstrak
Perilaku investasi merupakan faktor penting dalam menyiapkan anak berkualitas. Penelitian ini bertujuan untuk menganalisis perbedaan nilai anak, perilaku investasi, dan alokasi pengeluaran keluarga untuk investasi anak antara keluarga miskin dan tidak miskin. Selain itu, penelitian ini juga bertujuan untuk menganalisis pengaruh karakteristik keluarga, nilai anak, dan perilaku investasi terhadap alokasi pengeluaran keluarga untuk investasi anak. Penelitian ini melibatkan 55 keluarga yang memiliki anak sekolah dasar (kelas 1 dan 2) di Desa Kotabatu, Kecamatan Ciomas, Kabupaten Bogor, Provinsi Jawa Barat. Data dikumpulkan dengan cara mewawancarai ibu menggunakan kuesioner. Data dianalisis menggunakan uji beda t dan regresi linear berganda. Hasil penelitian menunjukkan bahwa nilai anak dan perilaku investasi anak pada keluarga miskin dan tidak miskin berbeda signifikan $(p<0,01)$. Persepsi nilai ekonomi yang dianut orang tua memiliki pengaruh signifikan negatif terhadap alokasi pengeluaran untuk investasi anak. Alokasi pengeluaran untuk investasi anak meningkat dengan bertambahnya jumlah anak sekolah.
\end{abstract}

Kata Kunci: alokasi pengeluaran, keluarga miskin, keluarga tidak miskin, nilai anak, perilaku investasi anak

\section{Child Investment Behavior of Poor and Nonpoor Families}

\begin{abstract}
Investment behavior is an important factor to reach qualified children outcomes. This study aimed to analyze the differences in value of children, the investment behaviors, and family expenditure allocation to investment between the children of poor and non-poor families. In addition, this study also aims to analyze the influence of family characteristics, the value of the child, and investment behavior towards children investment expenditure allocation. The study involved 55 families with elementary school children (grade 1 and 2) in Kotabatu village, Ciomas subdistrict, Bogor District, West Java Province. Data were collected by interviewing the mothers and using questionnaire. Data were analyzed using independent samples t-test and multiple linear regression. The results showed that value of children and children's investment behavior of poor and nonpoor families differ significantly $(p<0.01)$. Parent's perceptions of economic value had significant negative effect on the expenditures allocation for children's investment. The expenditures allocation for children's investment increased with the growing number of schooled children.
\end{abstract}

Keywords: children investment behavior, expenditures allocation, nonpoor family, poor family, value of children

\section{PENDAHULUAN}

Perbedaan kondisi sosial ekonomi keluarga akan menyebabkan perbedaan pada nilai anak yang dianut. Hernawati (2002) menemukan bahwa orang tua dengan tingkat sosial ekonomi rendah mempunyai nilai ekonomi anak yang lebih tinggi dibandingkan dengan orang tua dengan tingkat sosial ekonomi tinggi. Selain itu, perbedaan kondisi sosial ekonomi keluarga juga berdampak pada perbedaan perilaku investasi. Surachman \& Hartoyo (2012) telah menemukan bahwa keluarga tidak miskin yang kondisi sosial ekonominya tinggi memiliki perilaku investasi yang lebih baik dibandingkan dengan keluarga miskin yang kondisi sosial ekonominya rendah.

Perilaku investasi untuk anak ditentukan oleh persepsi orang tua terkait dengan nilai anak. Nilai anak didefinisikan sebagai fungsi anak yang bisa diberikan kepada orang tua atau kebutuhan yang bisa dipenuhi oleh anak bagi orang tua (Trommsdorff \& Nauck, 2005). Hasil penelitian Mulyani (2010) menemukan bahwa anak yang dinilai dapat memberikan manfaat ekonomi dan jaminan di hari tua akan menjadikan orang tua lebih bertanggung jawab sehingga akan melakukan investasi materi lebih banyak. 
Investasi orang tua terhadap anak merupakan salah satu upaya untuk menghasilkan sumberdaya yang berkualitas, salah satunya melalui alokasi uang dan waktu untuk pendidikan dan kesehatan (Bryant \& Zick, 2006). Masa di saat anak bersekolah merupakan saat orang tua aktif melakukan investasi kesehatan dan pendidikan anak. Keluarga dengan penghasilan tinggi akan mencurahkan lebih banyak sumber daya untuk meningkatkan kualitas anak (Hartoyo, 1998). Keluarga dengan pendapatan yang rendah akan mempersempit peluang keluarga untuk menyekolahkan anak sebagai investasi jangka panjang. Oleh karena itu, perlu dilihat sejauh mana perbedaan perilaku investasi untuk anak yang dilakukan oleh keluraga miskin dan tidak miskin, dan cara nilai anak dapat memengaruhi perilaku tersebut.

Penelitian ini bertujuan untuk menganalisis perbedaan alokasi pengeluaran, nilai anak, dan perilaku investasi untuk anak antara keluarga miskin dan tidak miskin. Penelitian juga dilakukan untuk menganalisis pengaruh karakteristik keluarga terhadap nilai anak. Selain itu, penelitian juga bertujuan untuk menganalisis pengaruh karakteristik keluarga dan nilai anak terhadap perilaku investasi orang tua untuk anak.

\section{METODE}

Penelitian dilakukan di Desa Kotabatu, Kecamatan Ciomas, Kabupaten Bogor, Provinsi Jawa Barat dengan menggunakan desain cross sectional. Desa Kotabatu dipilih secara purposive karena merupakan desa dengan jumlah penduduk terbanyak di Kabupaten Bogor, yaitu 22.084 jiwa. Pengambilan data dilakukan sejak bulan November sampai dengan bulan Desember tahun 2012.

Populasi dalam penelitian ini adalah keluarga miskin dan tidak miskin di lokasi penelitian yang mempunyai anak kelas I dan II Sekolah Dasar (SD) yang merupakan keluarga lengkap. Masa saat anak kelas I dan II SD merupakan masa awal anak memulai sekolah, pada masa ini orang tua cenderung aktif untuk memenuhi kebutuhan pendidikan dan kesehatan anak. Selanjutnya, pada desa Kotabatu dipilih dua RW secara acak, dan dari kedua RW tersebut didata keluarga yang memiliki anak kelas I dan II SD. Hasil pendataan menemukan bahwa terdapat 98 keluarga yang memenuhi syarat untuk menjadi contoh. Keluarga dibagi menjadi keluarga miskin dan tidak miskin berdasarkan data sekunder yang diperoleh dari kader posyandu di kedua RW terpilih. Selanjutnya, dari kerangka contoh tersebut dipilih 30 keluarga miskin dan 30 keluarga tidak miskin secara acak. Setelah cleaning data, jumlah contoh berkurang menjadi 55 keluarga yang terdiri atas 28 keluarga miskin dan 27 keluarga tidak miskin. Ibu dari keluarga contoh yang terpilih menjadi responden dalam penelitian ini.

Data primer didapatkan melalui penggalian informasi dari responden yang dilakukan dengan menggunakan kuesioner. Data tersebut terdiri atas karakteristik keluarga, nilai anak, perilaku investasi untuk anak, dan alokasi pengeluaran keluarga. Karakteristik keluarga terdiri atas jumlah anggota keluarga, usia ayah dan ibu, lama pendidikan ayah dan ibu, pendapatan keluarga, dan jumlah anak yang bersekolah.

Nilai anak adalah persepsi tentang keuntungan dan kerugian dalam mempunyai dan membesarkan anak yang dilihat secara psikologis, sosial, dan ekonomi. Nilai anak yang diukur adalah nilai anak berdasarkan persepsi ibu. Kuesioner untuk mengukur nilai anak terdiri atas 35 pertanyaan, yaitu 12 pertanyaan untuk nilai psikologis (Cronbach's alpha $=0,814$ ), 10 pertanyaan untuk nilai sosial (Cronbach's alpha $=0,778$ ), dan 13 pertanyaan untuk nilai ekonomi (Cronbach's alpha $=0,511$ ). Nilai anak dikategorikan menjadi tiga kategori yaitu rendah $(\leq 33,3 \%)$, sedang $(33,4 \%-66,6 \%)$, dan tinggi $(\geq 66,7 \%)$.

Perilaku investasi adalah tindakan dan biaya yang dikeluarkan oleh orang tua untuk menunjang pendidikan dan kesehatan anak. Kuesioner untuk mengukur perilaku investasi orang tua untuk anak terdiri atas 36 pertanyaan, yaitu 18 pertanyaan untuk perilaku investasi pendidikan (Cronbach's alpha $=0,652$ ) dan 18 pertanyaan untuk perilaku investasi kesehatan $(\alpha=0,708)$. Perilaku investasi dikategorikan menjadi tiga kategori yaitu rendah $(\leq 33,3 \%)$, sedang $(33,4 \%-66,6 \%)$, dan tinggi $(\geq 66,7 \%)$.

Alokasi pengeluaran investasi adalah jumlah uang (rupiah) yang dikeluarkan untuk investasi pendidikan dan kesehatan. Alokasi pendidikan anak adalah jumlah uang (rupiah) yang dikeluarkan untuk perlengkapan pendidikan seperti buku pelajaran anak, buku tulis anak, seragam anak, hobi anak, dan lainlain dalam satu bulan yang dinyatakan dalam rupiah. Alokasi kesehatan anak adalah jumlah uang (rupiah) yang dikeluarkan untuk memenuhi kebutuhan kesehatan anak baik untuk biaya kesehatan preventif maupun kuratif 
dalam satu bulan yang dinyatakan dalam rupiah.

Data dianalisis menggunakan analisis deskriptif dan statistik inferensial. Data dianalisis menggunakan uji beda $t$ dan $u j i$ regresi linear berganda. Uji beda digunakan untuk menguji perbedaan antara karakteristik anak dan keluarga, alokasi pengeluaran keluarga, nilai anak, dan perilaku investasi antara keluarga miskin dan tidak miskin. Uji regresi linear berganda digunakan untuk menganalisis pengaruh karakteristik keluarga terhadap nilai anak dan juga untuk menganalisis pengaruh karakteristik keluarga dan nilai anak terhadap perilaku investasi orang tua untuk anak.

\section{HASIL}

\section{Karakteristik Keluarga}

Jumlah anggota keluarga, usia ayah, usia ibu, dan jumlah anak bersekolah antara keluarga miskin dan tidak miskin tidak berbeda signifikan $(p>0,05)$. Sementara itu, pendidikan ayah, pendidikan ibu, dan pendapatan keluarga berbeda signifikan $(p<0,01)$ antara keluarga miskin dan keluarga tidak miskin. Nilai rata-rata untuk lama pendidikan ayah, lama pendidikan ibu, dan pendaparan keluarga pada keluarga tidak miskin lebih tinggi dibandingkan dengan keluarga miskin (Tabel 1).

Tabel 1 Nilai rata-rata, standar deviasi, dan koefisien uji beda karakteristik keluarga berdasarkan kategori kesejahteraan keluarga

\begin{tabular}{|c|c|c|c|}
\hline \multirow{2}{*}{$\begin{array}{l}\text { Karakteristik } \\
\text { keluarga }\end{array}$} & \multicolumn{2}{|c|}{ Rata-rata $\pm S t a n d a r$ deviasi } & \multirow{2}{*}{$p$-value } \\
\hline & Miskin & Tidak miskin & \\
\hline $\begin{array}{l}\text { Jumlah } \\
\text { anggota } \\
\text { keluarga } \\
\text { (orang) }\end{array}$ & $4,9 \pm 1,2$ & $4,3 \pm 1,2$ & 0,090 \\
\hline $\begin{array}{l}\text { Usia istri } \\
\text { (tahun) }\end{array}$ & $35,0 \pm 5,9$ & $33,6 \pm 6,1$ & 0,364 \\
\hline $\begin{array}{l}\text { Usia suami } \\
\text { (tahun) }\end{array}$ & $39,9 \pm 8,1$ & $38,3 \pm 6,0$ & 0,391 \\
\hline $\begin{array}{l}\text { Pendidikan } \\
\text { istri (tahun) }\end{array}$ & $5,6 \pm 3,0$ & $10,6 \pm 3,1$ & $0,000^{\star * *}$ \\
\hline $\begin{array}{l}\text { Pendidikan } \\
\text { suami } \\
\text { (tahun) }\end{array}$ & $6,8 \pm 2,8$ & $12,2 \pm 3,1$ & $0,000^{* * *}$ \\
\hline $\begin{array}{l}\text { Pendapatan } \\
\text { (Rp/kapita/ } \\
\text { bulan) }\end{array}$ & $160,7 \pm 74,3$ & $663,1 \pm 329,6$ & $0,000^{\star * *}$ \\
\hline $\begin{array}{l}\text { Jumlah anak } \\
\text { bersekolah } \\
\text { (orang) }\end{array}$ & $1,6 \pm 0,6$ & $1,7 \pm 0,9$ & 0,914 \\
\hline
\end{tabular}

\section{Nilai Anak}

Nilai psikologis anak adalah persepsi orang tua tentang keuntungan psikologis karena mempunyai dan membesarkan anak, seperti kesenangan, kegembiraan, dan kepuasan dalam memiliki anak (Kagitcibasi \& Ataca, 2005). Hasil penelitian menunjukkan bahwa sebagian besar keluarga miskin $(78,6 \%)$ dan keluarga tidak miskin $(100,0 \%)$ memiliki nilai psikologis anak pada kategori tinggi. Nilai psikologis anak antara keluarga miskin dan tidak miskin berbeda signifikan $(p<0,01)$. Ratarata nilai psikologis anak pada keluarga tidak miskin lebih tinggi dibandingkan dengan ratarata nilai psikologis anak pada keluarga miskin.

Nilai sosial anak adalah persepsi orang tua tentang keuntungan sosial karena mempunyai dan membesarkan anak, seperti meneruskan nama dan garis keturunan keluarga (Kagitcibasi \& Ataca, 2005). Hasil penelitian menunjukkan bahwa 64,3 persen keluarga miskin memiliki nilai sosial anak pada kategori sedang, sedangkan 66,7 persen keluarga tidak miskin memiliki nilai anak pada kategori tinggi. Nilai sosial anak antara keluarga miskin dan tidak miskin berbeda signifikan $(p<0,01)$. Rata-rata nilai sosial anak pada keluarga tidak miskin lebih tinggi dibandingkan dengan rata-rata nilai sosial anak pada keluarga miskin. Nilai minimum, maksimum, rata-rata, standar deviasi, dan koefisien uji beda untuk nilai psikologi dan sosial anak pada keluarga miskin dan tidak miskin disajikan pada Tabel 2.

Tabel 2 Nilai minimum, maksimum, rata-rata, standar deviasi, dan koefisien uji beda untuk nilai psikologi, sosial, dan ekonomi anak pada keluarga miskin dan tidak miskin

\begin{tabular}{|c|c|c|c|}
\hline Nilai anak & Miskin & Tidak Miskin & $p$-value \\
\hline \multicolumn{4}{|l|}{ Nilai psikologi } \\
\hline $\begin{array}{l}\text { Minimum- } \\
\text { maksimum }\end{array}$ & $55,6-91,7$ & $69,4-97,2$ & \\
\hline $\begin{array}{l}\text { Rata-rata } \pm \\
\text { standar deviasi }\end{array}$ & $74,5 \pm 10,1$ & $83,7 \pm 8,7$ & $0,002^{* * *}$ \\
\hline \multicolumn{4}{|l|}{ Nilai sosial } \\
\hline $\begin{array}{l}\text { Minimum- } \\
\text { maksimum }\end{array}$ & $56,7-93,3$ & $60,0-96,7$ & \\
\hline $\begin{array}{l}\text { Rata-rata } \pm \\
\text { standar deviasi }\end{array}$ & $68,6 \pm 8,1$ & $75,1 \pm 10,4$ & $0,001^{* * *}$ \\
\hline \multicolumn{4}{|l|}{ Nilai ekonomi } \\
\hline $\begin{array}{l}\text { Minimum- } \\
\text { maksimum }\end{array}$ & $46,2-84,6$ & $46,2-74,4$ & \\
\hline $\begin{array}{l}\text { Rata-rata } \pm \\
\text { standar deviasi }\end{array}$ & $59,3 \pm 7,9$ & $56,7 \pm 7,3$ & 0,204 \\
\hline
\end{tabular}



Nilai ekonomi anak adalah persepsi orang tua tentang keuntungan ekonomi karena mempunyai dan membesarkan anak, serta dalam memenuhi kebutuhan materi anak dari kecil hingga dewasa, dan cara anak menjaga orang tua di hari tua (Kagitcibasi \& Ataca, 2005). Hasil penelitian menunjukkan bahwa sebagian besar keluarga miskin $(92,9 \%)$ dan keluarga tidak miskin $(92,6 \%)$ memiliki nilai ekonomi anak pada kategori sedang. Nilai ekonomi anak antara keluarga miskin dan tidak miskin tidak berbeda signifikan $(p>0,05)$. Nilai minimum, maksimum, rata-rata, standar deviasi, dan koefisien uji beda untuk nilai psikologi, sosial, dan ekonomi anak pada keluarga miskin dan tidak miskin disajikan pada Tabel 2.

\section{Pengaruh Karakteristik Keluarga terhadap Nilai Anak}

Model yang disusun untuk menganalisis pengaruh karakteristik keluarga terhadap nilai psikologis memiliki koefisien determinasi sebesar 0,114 (Tabel 3). Hasil ini menjelaskan bahwa model yang disusun mampu menjelaskan 11,4 persen pengaruh karakteristik keluarga terhadap nilai psikologis. Berdasarkan hasil analisis, nilai anak pada dimensi psikologis dipengaruhi oleh kemiskinan keluarga $(B=7,230 ; p<0,05)$. Hal ini menjelaskan bahwa keluarga yang tidak miskin akan memengaruhi persepsi keluarga terhadap keuntungan psikologis yang dirasakan orang tua dalam memilik anak sebesar 7,230 poin.

Tabel 3 Koefisien regresi untuk menganalisis pengaruh karakteristik keluarga terhadap nilai psikologis

\begin{tabular}{|c|c|c|c|}
\hline Variabel & $\mathrm{B}$ & $\beta$ & Sig. \\
\hline $\begin{array}{l}\text { Usia istri } \\
\text { (tahun) }\end{array}$ & $-0,185$ & $-0,109$ & 0,487 \\
\hline $\begin{array}{l}\text { Lama } \\
\text { pendidikan } \\
\text { istri (tahun) }\end{array}$ & 0,202 & 0,078 & 0,649 \\
\hline $\begin{array}{l}\text { Kategori } \\
\text { Kemiskinan } \\
(0=\text { miskin; } \\
1=\text { tidak } \\
\text { miskin) }\end{array}$ & 7,230 & 0,357 & $0,037^{*}$ \\
\hline $\begin{array}{l}\text { Besar } \\
\text { keluarga } \\
\text { (orang) }\end{array}$ & 0,455 & 0,055 & 0,732 \\
\hline $\mathrm{F}$ & & & 2,731 \\
\hline Sig & & & $0,039^{* *}$ \\
\hline $\mathrm{R}$ & & & 0,423 \\
\hline $\begin{array}{l}\text { Adjusted R } \\
\text { Square }\end{array}$ & & & 0,114 \\
\hline
\end{tabular}

Model yang disusun untuk menganalisis pengaruh karakteristik keluarga terhadap nilai sosial memiliki koefisien determinasi sebesar 0,160 (Tabel 4). Hasil ini menjelaskan bahwa model yang disusun mampu menjelaskan 16,0 persen pengaruh karakteristik keluarga terhadap nilai sosial. Berdasarkan hasil analisis, nilai anak pada dimensi sosial dipengaruhi oleh pendapatan keluarga $\left(B=2,477 \times 10^{-6}, p<0,05\right)$. Pendapatan keluarga memiliki pengaruh positif dan signifikan terhadap nilai sosial $(B=2,477 \times 10-6, p<0,05)$. Hal ini menjelaskan bahwa keluarga dengan pendapatan besar akan memengaruhi persepsi nilai anak terhadap keuntungan sosial yang dirasakan orang tua dalam memiliki anak. Pendapatan dan kategori kemiskinan memiliki hubungan yang positif signifikan. Sehingga dapat dikatakan bahwa keluarga tidak miskin memiliki pendapatan tinggi.

Model yang disusun untuk menganalisis pengaruh karakteristik keluarga terhadap nilai ekonomi memiliki koefisien determinasi sebesar 0,161 (Tabel 5). Hasil ini menjelaskan bahwa model yang disusun mampu menjelaskan 16,1 persen pengaruh karakteristik keluarga terhadap nilai ekonomi. Berdasarkan hasil analisis, nilai anak pada dimensi psikologis dipengaruhi oleh usia suami $(B=0,435, p<0,01)$ dan jumlah anak sekolah $(B=-2,759, p<0,05)$. Usia ayah memiliki pengaruh negatif dan signifikan terhadap nilai ekonomi $(B=0,435$, $p<0,01)$. Hal ini berarti bahwa ayah dengan usia lebih tua memengaruhi persepsi orang tua tentang keuntungan ekonomi yang dirasakan orang tua karena memiliki anak. Lama pendidikan ayah juga memiliki pengaruh negatif dan signifikan terhadap nilai ekonomi $(B=-$ $0,636, p<0,05)$.

Tabel 4 Koefisien regresi untuk menganalisis pengaruh karakteristik keluarga terhadap nilai sosial

\begin{tabular}{|c|c|c|c|}
\hline Variabel & $\mathrm{B}$ & $\beta$ & Sig. \\
\hline Usia istri (tahun) & $-0,228$ & 0,139 & 0,374 \\
\hline $\begin{array}{l}\text { Lama pendidikan } \\
\text { istri (tahun) }\end{array}$ & 0,436 & 0,176 & 0,264 \\
\hline Pendapatan (rupiah) & $2,477 \times 10^{-}$ & 0,350 & $0,024^{* *}$ \\
\hline $\begin{array}{l}\text { Besar keluarga } \\
\text { (orang) }\end{array}$ & 2,068 & 0,259 & 0,100 \\
\hline $\mathrm{F}$ & & 3,575 & \\
\hline Sig. & & $0,012^{*}$ & \\
\hline $\mathrm{R}$ & & 0,472 & \\
\hline Adjusted $R$ square & & 0,160 & \\
\hline
\end{tabular}

Keterangan:

** Signifikan pada $p<0,05, B=$ Tidak terstandardisasi,

$\beta=$ Terstandardisasi 

Tabel 5 Koefisien regresi untuk menganalisis pengaruh karakteristik keluarga terhadap nilai ekonomi

\begin{tabular}{|c|c|c|c|}
\hline Variabel & $B$ & $\beta$ & Sig. \\
\hline $\begin{array}{l}\text { Usia suami } \\
\text { (tahun) }\end{array}$ & 0.435 & 0.405 & $0.006^{\star * *}$ \\
\hline $\begin{array}{l}\text { Lama } \\
\text { pendidikan } \\
\text { suami } \\
\text { (tahun) }\end{array}$ & -0.636 & -0.329 & $0.060^{*}$ \\
\hline $\begin{array}{l}\text { Kategori } \\
\text { Kemiskinan } \\
(0=\text { miskin; } \\
1=\text { tidak } \\
\text { miskin) }\end{array}$ & 1.558 & 0.103 & 0.552 \\
\hline $\begin{array}{l}\text { Jumlah } \\
\text { anak } \\
\text { sekolah } \\
\text { (orang) }\end{array}$ & -2.759 & -0.288 & $0.047^{* *}$ \\
\hline $\mathrm{F}$ & & & 3,599 \\
\hline Sig. & & & $0,012^{*}$ \\
\hline $\mathrm{R}$ & & & 0,473 \\
\hline $\begin{array}{l}\text { Adjusted R } \\
\text { Square }\end{array}$ & & & 0,161 \\
\hline
\end{tabular}

Hasil analisis pada Tabel 5 menunjukkan bahwa ayah dengan pendidikan rendah akan memengaruhi persepsi orang tua terntang keuntungan ekonomi yang dirasakan orang tua karena memiliki anak, sebesar 0,636 poin. Selain itu, jumlah anak sekolah memiliki pengaruh negatif dan signifikan terhadap nilai ekonomi $(B=-2,759, \quad p<0,05)$. Hal ini menjelaskan bahwa jumlah anak sekolah yang sedikit memengaruhi persepsi orang tua tentang keuntungan ekonomi yang dirasakan karena memiliki anak, sebesar 2,759 poin.

\section{Perilaku Investasi untuk Anak}

Investasi orang tua terhadap anak merupakan salah satu upaya yang dilakukan untuk menghasilkan sumber daya yang berkualitas, salah satunya melalui alokasi uang dan waktu untuk pendidikan dan kesehatan (Bryant \& Zick, 2006). Perilaku investasi pendidikan pada keluarga miskin (64,3\%) termasuk dalam kategori rendah, sedangkan perilaku investasi pendidikan pada keluarga tidak miskin $(77,8 \%)$ termasuk dalam kategori sedang. Perilaku investasi untuk pendidikan anak pada keluarga miskin dan tidak miskin berbeda signifikan $(p<0,01)$. Nilai rata-rata perilaku investasi pendidikan pada keluarga tidak miskin lebih baik dibandingkan dengan nilai rata-rata perilaku investasi pendidikan pada keluarga miskin. Nilai rata-rata, standar deviasi, dan koefisien uji beda disajikan pada Tabel 6 .
Tabel 6 Nilai minimum, maksimum, rata-rata, standar deviasi, dan koefisien uji beda perilaku investasi untuk anak pada keluarga miskin dan tidak miskin

\begin{tabular}{lcc}
\hline Kategori & $\begin{array}{c}\text { Perilaku } \\
\text { investasi } \\
\text { pendidikan }\end{array}$ & $\begin{array}{c}\text { Perilaku } \\
\text { investasi } \\
\text { kesehatan }\end{array}$ \\
\hline $\begin{array}{l}\text { Miskin } \\
\text { Minimum-Maksimum }\end{array}$ & $16,7-50,0$ & $16,7-66,7$ \\
$\begin{array}{l}\text { Rata-rata } \pm \text { Standar } \\
\text { deviasi }\end{array}$ & $33,1 \pm 9,6$ & $36,5 \pm 12,1$ \\
$\begin{array}{l}\text { Tidak miskin } \\
\text { Minimum-Maksimum }\end{array}$ & $33,3-72,2$ & $38,9-77,8$ \\
$\begin{array}{l}\text { Rata-rata } \pm S t a n d a r \\
\text { deviasi }\end{array}$ & $53,9 \pm 11,6$ & $59,9 \pm 13,5$ \\
\hline $\begin{array}{l}\text { p-value } \\
\text { Keterangan: }\end{array}$ & $0,000^{* * *}$ signifikan pada $p<0,01$ & $0,000^{* * *}$ \\
\hline
\end{tabular}

Perilaku investasi kesehatan pada keluarga miskin $(53,6 \%)$ dan tidak miskin $(74,1 \%)$ termasuk dalam kategori sedang. Perilaku investasi untuk kesehatan anak pada keluarga miskin dan tidak miskin berbeda signifikan $(p<0,01)$. Nilai rata-rata perilaku investasi kesehatan pada keluarga tidak miskin lebih baik dibandingkan dengan nilai rata-rata perilaku investasi kesehatan pada keluarga miskin (Tabel 6).

\section{Pengaruh Karakteristik Keluarga terhadap Perilaku Investasi Anak}

Model yang disusun untuk menganalisis pengaruh karakteristik keluarga terhadap perilaku investasi anak memiliki koefisien determinasi (Adjusted $R$ Square) sebesar 0,659 . Koefisien regresi untuk model tersebut disajikan pada tabel 7 .

Tabel 7 Koefisien regresi untuk menganalisis pengaruh karakteristik keluarga terhadap perilaku investasi anak

\begin{tabular}{|c|c|c|c|}
\hline Variabel & $\mathrm{B}$ & $\mathrm{B}$ & Sig. \\
\hline Usia istri (tahun) & $-0,038$ & $-0,016$ & 0,863 \\
\hline Pendidikan istri tahun) & 1,194 & 0,339 & $0,003^{* *}$ \\
\hline $\begin{array}{l}\text { Kemiskinan }(0=\text { miskin; } \\
1=\text { tidak miskin })\end{array}$ & 10,450 & 0,379 & $0,001^{* *}$ \\
\hline $\begin{array}{l}\text { Jumlah anak sekolah } \\
\text { (orang) }\end{array}$ & $-1,179$ & $-0,068$ & 0,481 \\
\hline Nilai psikologis (skor) & 0,207 & 0,152 & 0,122 \\
\hline Nilai sosial (skor) & 0,274 & 0,193 & $0,069^{*}$ \\
\hline Nilai ekonomi (skor) & $-0,172$ & $-0,095$ & 0,330 \\
\hline $\mathrm{F}$ & \multicolumn{3}{|c|}{15,913} \\
\hline Sig. & \multicolumn{3}{|c|}{$0,000^{* * *}$} \\
\hline $\mathrm{R}$ & \multicolumn{3}{|c|}{0,839} \\
\hline Adjusted $R$ square & \multicolumn{3}{|c|}{0,659} \\
\hline
\end{tabular}



Berdasarkan hasil pada Tabel 7, lama pendidikan istri berpengaruh positif signifikan terhadap perilaku investasi anak $(B=1,194$, $p<0,01)$. Kategori kemiskinan keluarga berpengaruh positif signifikan terhadap perilaku investasi anak $(B=10,450, p<0,01)$. Variabel lain yang ditemukan berpengaruh adalah nilai sosial anak yang berpengaruh positif signifikan terhadap perilaku investasi anak $(B=0,274$, $p<0,05)$. Hasil ini menunjukkan bahwa pendidikan istri yang semakin meningkat, kesejahteraan keluarga yang semakin bertambah, dan nilai sosial anak yang semakin meningkat akan berpengaruh terhadap meningkat perilaku investasi anak.

\section{Alokasi Pengeluaran untuk Investasi Anak}

Alokasi pengeluaran investasi anak adalah pengeluaran yang dilakukan untuk kebutuhan kesehatan, pendidikan dan jajan atau uang saku anak yang bersekolah. Berdasarkan alokasi pengeluaran yang dikeluarkan keluarga untuk kebutuhan kesehatan, pendidikan dan jajan atau uang saku, dapat dilihat bahwa alokasi pengeluaran untuk anak berbeda sesuai dengan jenjang pendidikan, dan jumlah anak. Keluarga yang memiliki anak dengan tingkat pendidikan diploma memiliki pengeluaran lebih besar, yaitu rata-rata sebesar Rp1.450.000,00 per bulan, dengan persentase 3,5 persen dari total alokasi pengeluaran investasi anak.

Berdasarkan jenis pengeluaran yag dilakukan untuk anak, dapat dilihat bahwa baik pada keluarga miskin maupun keluarga tidak miskin alokasi untuk jenis pengeluaran uang saku lebih besar daripada untuk pengeluaran pendidikan dan kesehatan. Akan tetapi pada keluarga miskin $(11,9 \%)$ proporsi uang saku atau uang jajan anak lebih besar daripada keluarga tidak miskin $(9,6 \%)$. Namun untuk proporsi pegeluaran pendidikan $(3,1 \%)$ dan kesehatan $(0,5 \%)$ pada keluarga miskin lebih rendah daripada keluarga tidak miskin untuk proporsi pengeluaran pendidikan $(4,7 \%)$ dan kesehatan $(1,9 \%)$.

\section{Pengaruh Karakteristik Keluarga, Nilai, dan Perilaku Investasi terhadap Alokasi Pengeluaran Keluarga untuk Investasi Anak}

Tabel 8 menunjukkan variabel-variabel yang memengaruhi alokasi pengeluaran untuk investasi anak. Hasil uji regresi memperlihatkan nilai Adjusted $R$ Square sebesar 0,432, artinya model ini hanya menjelaskan 43,2 persen variabel-variabel yang memengaruhi alokasi pengeluaran investasi anak $(p<0,01)$.
Tabel 8 Koefisien regresi untuk menganalisis pengaruh karakteristik keluarga, nilai anak, dan perilaku investasi anak terhadap alokasi pengeluaran keluarga untuk investasi anak

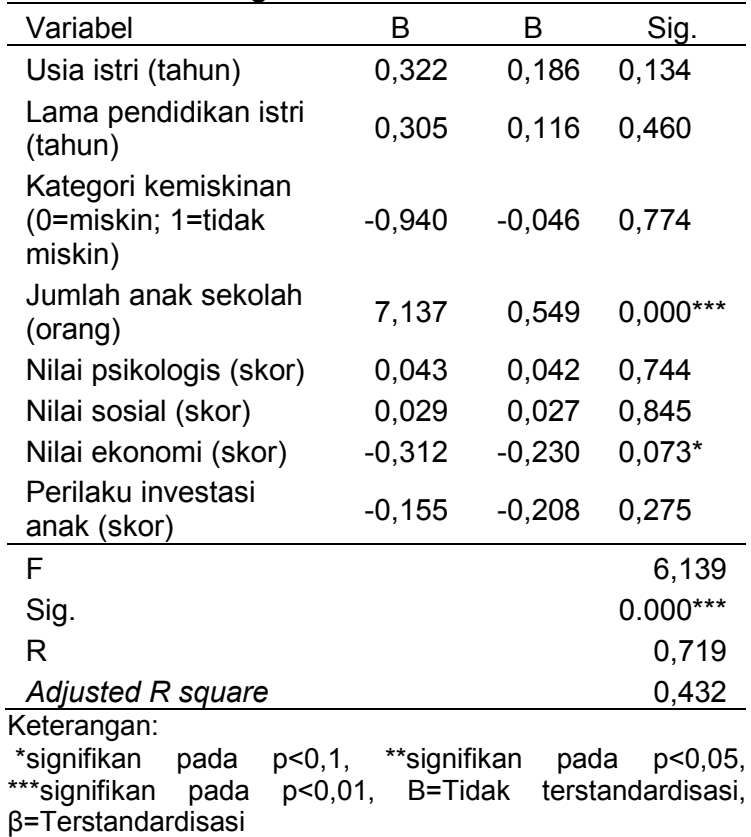

Hasil analisis regresi yang disajikan pada Tabel 8 menunjukkan bahwa jumlah anak sekolah berpengaruh positif dan signifikan terhadap alokasi pengeluaran investasi anak $(B=7,137, p<0,01)$. Sementara itu, nilai ekonomi anak memiliki pengaruh negatif dan signifikan terhadap alokasi pengeluaran investasi anak $(B=-0,312, \quad p<0,1)$. Hasil ini menunjukkan bahwa peningkatan jumlah anak yang bersekolah dan menurunnya nilai ekonomi anak akan berpengaruh terhadap penambahan alokasi pengeluaran keluarga yang digunakan untuk investasi anak.

\section{PEMBAHASAN}

Hasil penelitian ini menemukan nilai psikologis anak merupakan nilai dengan ratarata tertinggi dibandingkan dengan dimensi lain. Menurut Hastuti, Alfiasari, \& Chandriyani (2010), sebagian orang tua responden mempunyai harapan nilai psikologis yang tinggi terhadap anaknya. Orang tua mengharapkan anak bisa memberikan kebahagiaan bagi orang tua. Hasil penelitian ini menemukan bahwa rata-rata nilai psikologis keluarga tidak miskin lebih tinggi dibandingkan dengan keluarga miskin, dan uji beda antara keduanya menunjukkan perbedaan yang signifikan. Hasil uji pengaruh terhadap nilai psikologi menunjukkan bahwa kategori kemiskinan keluarga memiliki pengaruh positif signifikan terhadap semakin tingginya nilai ekonomi yang 

dianut keluarga. Oleh karena itu, dapat dikatakan bahwa dalam penelitian ini keluarga tidak miskin lebih puas dan bahagia memiliki anak. Nilai psikologis mencerminkan kebahagiaan dan kepuasan orang tua dalam memiliki anak (Kagitcibasi \& Ataca, 2005). Oleh karena itu, dalam penelitian ini dapat dikatakan bahwa keluarga tidak miskin lebih merasa bahagia, senang, dan puas terhadap kehadiran anak dalam kehidupannya.

Kagitcibasi \& Ataca (2005) juga menyatakan bahwa nilai sosial anak adalah bagaimana penerimaan lingkungan sosial terhadap anak. Penelitian ini menemukan bahwa rata-rata nilai sosial keluarga tidak miskin lebih tinggi dibandingkan dengan keluarga miskin, dan uji beda menunjukkan perbedaan yang signifikan antara keduanya. Hal ini berarti bahwa keluarga tidak miskin cenderung memiliki persepsi lebih tinggi tentang keuntungan sosial karena memiliki dan membesarkan anak. Hasil penelitian ini menemukan bahwa pendapatan memiliki pengaruh positif dan signifikan terhadap nilai sosial anak. Keluarga tidak miskin dalam penelitian ini memiliki pendapatan lebih tinggi sehingga memiliki kesempatan lebih untuk menyekolahkan anak ke sekolah unggulan karena orang tua menginginkan anak mereka mendapatkan lingkungan sosial menengah keatas. Oleh karena itu, dapat dikatakan bahwa keluarga tidak miskin menganggap bahwa kehadiran anak memberikan keuntungan sosial.

Sementara itu, berbeda dengan hasil pada nilai psikologi dan nilai sosial, rata-rata nilai ekonomi keluarga miskin lebih tinggi dibandingkan dengan keluarga tidak miskin. Meskipun keduanya tidak berbeda signifikan. Hal ini berarti bahwa keluarga miskin lebih setuju bahwa dengan memiliki anak, orang tua merasakan keuntungan secara ekonomi, baik dalam membantu perekonomian keluarga disaat sekarang, maupun diharapkan sebagai tulang punggung keluarga. Hasil uji pengaruh terhadap nilai ekonomi anak menunjukkan bahwa usia suami, lama pendidikan suami, dan jumlah anak sekolah memiliki pengaruh terhadap nilai ekonomi. Oleh karena itu dapat dikatakan bahwa anak diharapkan untuk memberikan bantuan ekonomi disaat sekarang maupun nanti disaat tua, ataupun memberikan bantuan dalam menyelesaikan pekerjaan rumah tangga.

Persepsi orang tua terkait nilai anak juga memengaruhi perilaku investasi anak yang dilakukan keluarga. Peningkatan skor nilai sosial anak akan menaikkan skor perilaku investasi anak. Hal ini sejalan dengan penelitian Surachman dan Hartoyo (2012), yang menemukan bahwa skor nilai anak memiliki hubungan positif signifikan dengan perilaku investasi. Orang tua akan mengharapkan anak menjadi seseorang yang lebih sukses dan menjaga nama baik keluarga di masa depan. Hal ini membuat orang tua terutama ibu melakukan perilaku investasi yang lebih baik untuk anak dengan cara memberikan kesempatan anak untuk mendapatkan ilmu pengetahuan lebih baik, menemani anak belajar, serta memberikan makanan yang lebih bergizi.

Hasil lain penelitian ini menemukan bahwa keluarga yang tidak miskin memiliki pengaruh lebih positif secara signifikan terhadap perilaku investasi anak yang dilakukan. Keluarga tidak miskin dalam penelitian ini melakukan perilaku investasi pendidikan dan kesehatan yang lebih baik untuk anak, seperti menyediakan tabungan untuk pendidikan dan kesehatan anak, menyediakan buku bacaan, VCD pembelajaran, menyediakan tempat khusus untuk belajar, dan menyediakan makanan bergizi.

Selain itu, lama pendidikan ibu juga berpengaruh terhadap perilaku investasi yang dilakukan. Hasil ini sejalan dengan temuan penelitian Rosidah, Hartoyo, \& Muflikhati (2012) bahwa bertambahnya lama pendidikan ibu untuk mengikuti pendidikan formal dapat meningkatkan perilaku investasi anak. Ibu yang memiliki tingkat sosial ekonomi tinggi dalam penelitian ini merupakan kelompok keluarga tidak miskin dan memiliki rata-rata tingkat pendidikan yang lebih tinggi. Oleh karenanya, ibu lebih memiliki pengetahuan dan memiliki kemampuan sosial ekonomi yang lebih baik sehingga ibu melakukan perilaku investasi yang lebih baik, seperti lebih suka memuji anak dengan menggunakan bahasa Indonesia yang baik dan sopan, serta mengajak anak mengunjungi museum untuk menambah pengetahuan anak.

Hasil uji beda juga menunjukkan perbedaan perilaku investasi pendidikan dan kesehatan antara keluarga miskin dan tidak miskin. Rata-rata skor perilaku investasi pendidikan dan kesehatan keluarga tidak miskin lebih tinggi dibandingkan dengan keluarga miskin. Anak dari keluarga miskin dalam penelitian ini banyak yang tidak memiliki buku pendamping belajar yang digunakan di sekolah, yaitu buku Lembar Kerja Siswa (LKS). Selain itu, angka putus sekolah anak keluarga miskin juga lebih tinggi dibandingkan dengan keluarga tidak miskin yang mencapai 46,4 persen, bahkan beberapa anak keluarga miskin terpaksa putus sekolah dan bekerja untuk membantu perekonomian keluarga. 

Bryant \& Zick (2006) menyatakan bahwa investasi pada anak juga mencakup investasi uang (seperti uang yang digunakan untuk memperoleh makanan, pakaian, rumah, transportasi, pendidikan, dan perawatan kesehatan). Oleh karena itu, investasi yang dilakukan oleh orang tua juga diukur melalui alokasi uang yang dikeluarkan orang tua untuk anak. Hasil uji pengaruh menunjukkan bahwa alokasi pengeluaran investasi anak dipengaruhi negatif oleh nilai ekonomi anak. Dalam penelitian ini orang tua dari keluarga miskin memiliki rata-rata nilai ekonomi yang lebih tinggi. Oleh karena itu, orang tua keluarga miskin tidak memiliki kemampuan ekonomi lebih terutama alokasi uang untuk menunjang orang tua dalam melakukan perilaku investasi anak yang lebih baik. Hal ini dapat dilihat dari jumlah anak bersekolah pada keluarga miskin yang lebih rendah.

Penelitian ini juga menunjukkan bahwa jumlah anak sekolah memiliki pengaruh terhadap alokasi pengeluaran investasi yang dilakukan oleh keluarga. Penambahan satu orang anak sekolah akan menaikkan persentase alokasi pengeluran investasi yang dilakukan keluarga. Rosidah, Hartoyo, dan Muflikhati (2012) juga menemukan bahwa jumlah anak sekolah menjadi salah satu faktor yang berpengaruh pada alokasi pengeluaran untuk anak. Pertambahan jumlah anak yang sekolah dapat meningkatkan pengeluaran keluarga yang dialokasikan untuk pendidikan dan kesehatan anak. Dalam penelitian ini keluarga tidak miskin memiliki total pengeluaran, alokasi pengeluaran untuk anak, dan perilaku investasi anak yang lebih tinggi dibandingkan keluarga miskin. Hartoyo (1998) menyatakan bahwa keluarga dengan pendapatan tinggi akan mencurahkan sumberdaya untuk meningkatkan kualitas anak.

\section{SIMPULAN DAN SARAN}

Keluarga miskin memiliki nilai psikologi yang tinggi dan juga memiliki nilai sosial dan ekonomi yang sedang. Sementara itu, keluarga tidak miskin memiliki nilai psikologi dan sosial yang tinggi, serta nilai ekonomi pada kategori sedang. Nilai psikologi dan nilai sosial yang dimiliki oleh keluarga tidak miskin lebih baik dibandingkan keluarga miskin. Nilai psikologi dapat meningkat dengan bertambahnya kesejahteraan keluarga, pertambahan pendapatan keluarga juga dapat meningkatkan nilai sosial. Sementara itu, bertambahnya usia suami dapat menurunkan nilai ekonomi anak, sedangkan lama pendidikan suami, dan jumlah anak bersekolah dapat meningkatkan nilai ekonomi anak.

Perilaku investasi pendidikan keluarga miskin tergolong rendah (investasi pendidikan) dan sedang (investasi kesehatan), sedangkan perilaku investasi pendidikan dan kesehatan pada keluarga tidak miskin tergolong dalam kategori sedang. Keluarga tidak miskin dalam penelitian ini akan melakukan perilaku investasi pendidikan dan kesehatan yang lebih baik dibandingkan dengan keluarga miskin. Perilaku investasi dapat meningkat dengan bertambahnya lama pendidikan istri, kesejahteraan keluarga, dan nilai sosial anak.

Investasi yang dilakukan orang tua untuk anak juga diukur melalui alokasi uang yang dikeluarkan orang tua untuk pendidikan dan kesehatan anak. Jumlah anak bersekolah ditemukan memiliki pengaruh positif dan signifikan terhadap alokasi pengeluaran investasi anak. Akan tetapi persepsi nilai ekonomi yang dianut orang tua ditemukan memiliki pengaruh negatif signifikan terhadap alokasi pengeluaran investasi anak.

Penelitian ini menunjukkan bahwa penambahan satu orang anak yang bersekolah akan menaikkan alokasi pengeluaran investasi yang dilakukan. Oleh karena itu, keluarga disarankan untuk mempersiapkan tabungan sebelum anak-anak bersekolah, agar saat anak masuk sekolah orang tua tidak kesulitan untuk membiayai sekolah.

\section{DAFTARA PUSTAKA}

Bryant, W. K., \& Zick, C. D. (2006). The economic organization of the household, second edition. Cambridge, UK: Cambridge University Press.

Hartoyo. (1998). Investing in children: Study of rural families in Indonesia (disertasi). Blacksburg, US: Virginia Tech University

Hastuti, D., Alfiasari, \& Chandriyani. (2010). Nilai anak, stimulasi psikososial, terhadap perkembangan kognitif anak usia 2-5 tahun pada keluarga rawan pangan di Kabupeten Banjarnegara, Jawa Tengah. Jurnal ilmu Keluarga \& Konsumen, 3(1), 27-34.

Hernawati, N. (2002). Nilai anak dan pengasuhan berdasarkan gender pada anak usia 2-3 tahun (skripsi). Institut Pertanian Bogor, Bogor. 

Kagitcibasi, C., \& Ataca, B. (2005). Value of children and family change: A tree-decade potrait from turkey. Applied Psyichology:An International Review, 54(3), 317-337.

Mulyani, S. R. (2010). Studi nilai anak, jumlah anak yang diinginkan, dan keikutsertaan keluarga dalam program KB di Desa Bojongrangkas, Kecamatan Ciampea, Kabupaten Bogor (skripsi). Institut Pertanian Bogor, Bogor.

Rosidah, U., Hartoyo, \& Muflikhati, I. (2012). Kajian strategi koping dan perilaku investasi anak pada keluarga buruh pemetik melati gambir. Jurnal ilmu Keluarga \& Konsumen, 5(1), 77-87.

Surachman, A., \& Hartoyo. (2012). Born to be Destitute: Capital Transfer and Intergenerational Transfer of Proverty. Undergraduate Research Journal for the Human Science, URJH, 11. Diambil dari http//www.kon.org/urc/v11/surachman.html . [diunduh 29 Jan 2013].

Trommsdorff, G.,\&Nauck, B. (2005). Value of children in cross-cultural perspective. Case of studies from eight societies. Lengerich: Pabst Science,9-16. 